\title{
Influence of seasonal dynamics on groundwater resources quality in semi- tropical urban zone: case of the Biyémé upper stream catchment (Yaounde, Cameroon)
}

\author{
François NTEP ${ }^{1-2^{*}}$, Ives Magloire KENGNE ${ }^{2}$, Guillaume EWODO MBOUDOU ${ }^{1-3}$, \\ NKEZE NYOCHEMBENG ${ }^{2}$ and Georges Emmanuel EKODECK ${ }^{1}$ \\ ${ }^{I}$ Laboratory of Engineering Geology and Alterology, Department of Earth Science; \\ Faculty of Science, University of Yaounde 1, P.O Box. 812 Yaounde, Cameroon. \\ ${ }^{2}$ Wastewater Research Unit (WRU), Department of Plant Biology, Faculty of Science, \\ University of Yaounde 1, P.O Box. 812 Yaounde, Cameroon. \\ ${ }^{3}$ Higher Institute of Sahel, University of Maroua, P.O Box. 46 Maroua, Cameroon. \\ *Corresponding author, E-mail: francoisntep@yahoo.fr; Tel: (237) 9935 38 70; 76099475
}

\begin{abstract}
Located at $3^{\circ} 51^{\prime} 97^{\prime \prime}$ to $3^{\circ} 49^{\prime} 97^{\prime \prime} \mathrm{N}$ and $11^{\circ} 28^{\prime} 85^{\prime \prime}$ to $11^{\circ} 29^{\prime} 89^{\prime \prime} \mathrm{E}$ in the SW of Yaounde, the Biyémé upper stream catchment covers a surface area of 500 ha. It harbours a population of about 400,000 people whose major modes of water supply are wells and springs. The main objective of this research was to study the groundwater quality through combined piezometric and physicochemical and bacteriological data interpretations. From July 2008 to June 2009, 16 wells and 05 springs within the study area were selected and monitored on a bimonthly basis. Results showed low mean annual amplitude of the water table, which varies between $0.49 \mathrm{~m}$ for wells in lowlands to $1.30 \mathrm{~m}$ for wells in the ridge. Almost $97 \%$ of wells and $10 \%$ of springs had values of nitrates higher than the $11.36 \mathrm{~N}^{-\mathrm{NO}_{3}}{ }^{-}$guideline recommended by WHO for drinkable water, especially during dry seasons. This underground water also revealed microbial contamination, with values of faecal indicators higher than the $0 \mathrm{UFC} / 100 \mathrm{ml}$ recommended by WHO, but mostly during raining seasons. Anarchic urbanization and inadequate hygiene conditions are factors enhancing the sanitary risk of these water points.
\end{abstract}

(c) 2014 International Formulae Group. All rights reserved.

Keywords: Biyémé catchment, hydrodynamics, sanitary risk, seasons, underground water, water quality.

\section{INTRODUCTION}

Most of sub-Saharan Africa cities lack adequate access to basic services (water, electricity, refuse collection and rehabilitation). Among these services, a safe, reliable, affordable, and easily accessible water supply is essential for good health (Hunter et al., 2010). Yaounde, like other cities of developing countries, is subject to numerous stress factors at the rank of which pollution of water resources occupies a good position. Indeed, more than $75 \%$ of installations for the evacuation of excreta are deep traditional pit latrines, sometimes in contact with water table (Bemmo et al., 1998). Despite the efforts made by the authorities in place to supply the population with drinkable water, lots remain to be done. Djeuda 
Tchapnga et al. (2001) reported that less than $2 / 3$ of the population had access to water distribution network of CAMWATER (Cameroon Water Utilities Corporation), the Cameroon National Water Utilities, for a population estimated at about two million inhabitants. Since 2008, CAMWATER hardly distributes $100,000 \mathrm{~m}^{3}$ of water per day, for a demand evaluated at more than $300,000 \mathrm{~m}^{3}$ for a population nearly 2 million inhabitants. Hence, to meet up with this deficit, the populations generally seek recourse to alternative modes of drinking water supply such as springs and wells, which are not always of good quality. Underground waters have long been presented as unfavorable environments for bacterial life (Gounot, 1994). Therefore, the origin of bacteria in these waters is frequently disputed. Frenchel (2001) suggests that they originate from anaerobic soil microorganisms that must have undergone mutation. The process of transfer of these microorganisms from the soil to underground water is complex (Abu-Ashur et al., 1998). It is regulated by the physicochemical and hydraulic properties of the collecting soil, the morpho-anatomical and physiological properties of the microorganisms, among others (Growe et al., 2003; Sanin, 2004). Little knowledge exists on the mechanisms of transfer of pollutants from soils to aquifer in different environmental media. Some works have previously been carried out in sandy environment, in Togo and Niger (BabaMoussa, 1994; Chippaux et al., 2002 and Boubakar Hassane, 2010) or grit-sandy environment in Morocco (Saadia et al., 2007). The conclusions of these studies cannot however be generalized without bias in crystalline environment where there is a general water flow direction. In recent years, the World Health Organisation (WHO) has promoted the idea of Water Safety Plans (WSPs) (Davison et al., 2005). A WSP is a risk-based approach to public health achieved through water quality and catchment management strategies under the slogan
" "managing drinking water quality from catchment to consumer', Although the WSP approach is widely used in urban piped supply water systems, there have been few attempts to implement the approach in rural settings, where distant water sources are the norm (Howard G. 2003; Mahmud et al., 2007). The present study is a characterization of the mean annual dynamics of the physicochemical and bacteriological pollution of aquifer in a fissured environment. It presents the pollution dynamics of underground waters of the study area in relation to seasonal pluviometric fluctuations.

\section{MATERIALS AND METHODS \\ Presentation of study area}

This study was carried out in the Biyémé upper stream catchment located in the SW of Yaounde. It is part of the Mfoundi catchment. Yaounde covers a surface of approximately $256 \mathrm{~km}^{2}$, ranging between $3^{\circ}$ and $5^{\circ}$ North and $11^{\circ}$ and $12^{\circ}$ East (Kamgang and Ekodeck, 1991). The population of Yaounde, evaluated at 1,800,000 inhabitants, undergoes a growth rate ranging between 3.5 and $6.2 \%$ annually and density varies from 3.2 to 5.69 inhabitants $/ \mathrm{km}^{2}$ (Bucrep, 2005). The hydrographic network constitutes a set of perennial rivers. The geological substratum is composed of a set of fractured Precambrian formations, constituting aquiferous reservoirs exploitable through wells and boreholes (Nzenti, 1987). Yaounde is imbued with a strongly accidented relief with a mean altitude at $730 \mathrm{~m}$. Soils are red and ferralitic in majority. The reigning climate is the equatorial type (Kamgang and Ekodeck, 1991; Sighomnou, 2004). The climate is of the equatorial type with two rainy seasons (AprilJune and September-October) and two dry seasons (November-March and July-August) annually. Figure 1 shows the variations of monthly rainfall in the Yaounde town throughout the period from July 08 to June 09, done with meteorological data, recorded at the pluviometric station of 105 Air force base. 
Choice of water points for the study of the contamination of the aquifer

Criteria for the selection of water points were: -i) a good spatial distribution of water points on the study site, -ii) the relative importance for the user populations; a water point is more important when the volume of water carried is high and or if the water carried is preliminarily meant for human consumption -iii) the level of development of the water point and its topographic position in the basin (ridge, mid-slope or lowland), -iv) the disqualification of floodable wells in order to avoid the influence of artificial floods on the water point and -v) the initial water level in the well in order to monitor the eventual fluctuations of the water table. The above factors led to the retention of 16 wells (13.34 $\%$ ) and all the five springs in the area for follow-up. Figure 2 shows the distribution of selected wells and springs for study with respect to topographic levels of the catchment.

\section{Hydrodynamic characterization of aquifer Measure of flow rates}

The measure of flow rates of springs was determined by the gauging of standardized reservoirs method. This rather simple technique consists in measuring the time required to fill a graduated bucket of known volume, using a stop watch (Laborde, 2009).

\section{Determination of the dynamic level of the water table}

This was done as follows (Figure 3): the experimenter holds a double decametre to which a suspensor is attached with the role of maintaining the rope stretched when it is plunged in the well. Reading is made when the suspensor tip touches the surface of the water, thereby provoking the formation of ripples. In order to minimize the effect of normal water carrying from the wells by the population, measures of the water table drawdown were done every middle and last day of each month (bimonthly) between 10 am and $2 \mathrm{pm}$, throughout the study period. This time happens to be the period when little or no water drawing activity is carried out on the well.

\section{Physicochemical and biological characterization of aquifer Physicochemical determination}

Physicochemical parameters were measured according to standard methods for the examination of water and wastewater (Eaton et al., 2005). Parameters of interest were Temperature (T), Electrical Conductivity (EC) and $\mathrm{pH}$ measured in situ during the sampling operations with the aid of the Hach portable multi-meters models $11 \mathrm{~d}$ and $14 \mathrm{~d}$. Ions ammonium $\left(\mathrm{N}-\mathrm{NH}_{3}{ }^{+}\right)$, nitrate $\left(\mathrm{N}-\mathrm{NO}_{3}{ }^{+}\right)$, sulphate $\left(\mathrm{SO}_{4}{ }^{3-}\right)$, chloride $\left(\mathrm{Cl}^{-}\right)$, magnesium $\left(\mathrm{Mg}^{2+}\right)$ and calcium $\left(\mathrm{Ca}^{2+}\right)$ were determined by colored method with Hach spectrophotometer model DR 2010. Ions sodium $\left(\mathrm{Na}^{+}\right)$and potassium $\left(\mathrm{K}^{+}\right)$by excitation of atoms with flame photometer model Jenway PFP 7 while, ions carbonate $\left(\mathrm{CO}_{3}{ }^{-}\right)$and hydro-carbonate $\left(\mathrm{HCO}_{3}{ }^{-}\right)$by titration method with $\mathrm{HCl} 0,1 \mathrm{~N}$. Chemical features are described on the basis of chemical analyses on the water samples from the wells and springs studied in the catchment. These analyses were made at the Laboratory of Inorganic Chemistry and the Laboratory of Wastewater Research Unit (WRU), Faculty of Sciences, University of Yaounde I. Data collected were analyzed using XLSTAT and Microsoft Excel 2010 softwares.

\section{Determination of bio-indicators of faecal pollution}

The determination of faecal coliforms and streptococci was carried out by the membrane filtration method using appropriate media under sterile conditions (Rodier, 2009) at the WRU. The concentration of measured bio-indicators is expressed as colony forming unit (CFU) per unit volume of $100 \mathrm{ml}$ as follows:

$\mathrm{CFU} / 100 \mathrm{~mL}=\frac{\text { Nomber of counted colonies }}{\text { volume of filtered sample }} \times 100$ 


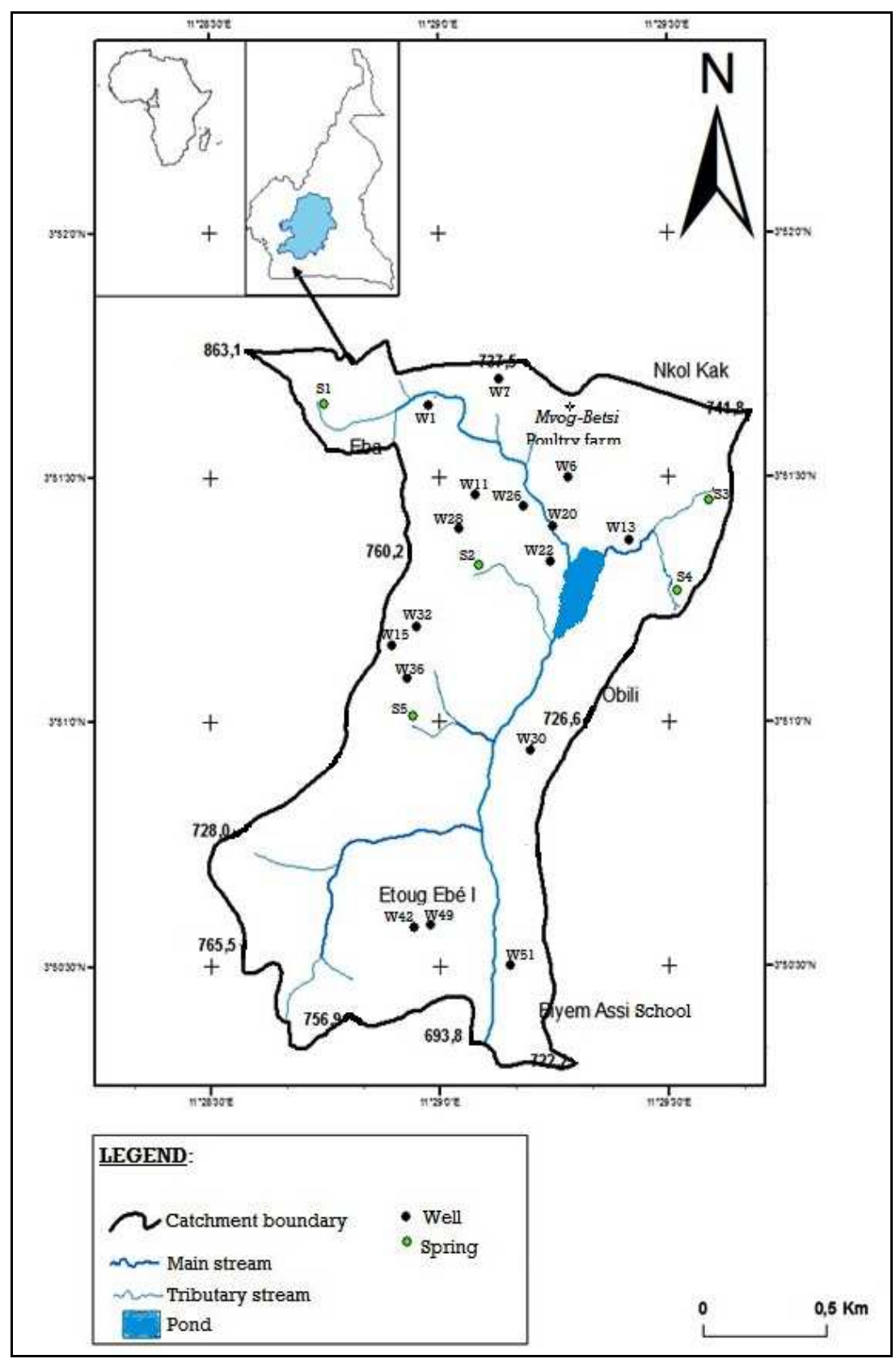

Figure 2: Location map of the 21 selected sampling wells and springs in the Biyémé upper stream catchment. 


\section{RESULTS \\ Hydrodynamic characteristics Wells in lowlands}

Wells in lowlands showed weak fluctuations during the study year. Mean seasonal fluctuations ( Figure 4a) show that the water table passes through a minimum level $(1.69 \mathrm{~m})$ in October (flood) and a maximum $(2.31 \mathrm{~m})$ in January (low water), indicating that the recharge of the aquifer occurs during the rainy season. Differences in water levels between high and low waters in these wells vary between $1.76 \mathrm{~m}$ and $1.27 \mathrm{~m}$ giving an annual mean amplitude of $\Delta_{1}=0.49$ $\mathrm{m}$.

\section{Wells in mid-slope}

In these topographic positions, the deepest water does not exceed $10 \mathrm{~m}$. The mean seasonal fluctuations (Figure 4b) show that in these wells and contrary to the wells in lowlands, water attains its minimum level $(6.34 \mathrm{~m})$ in January and February (low water) and its maximum $(7.24 \mathrm{~m})$ in April (flood). Here, the water level differences between low and high waters vary between $6.74 \mathrm{~m}$ and 6.09 $\mathrm{m}$, thus representing a mean annual amplitude of $\Delta_{2}=0.65 \mathrm{~m}$.

\section{Wells in ridge}

In high altitudes, depths of water in the soil are quite important, reaching up to $17 \mathrm{~m}$ like in the well $\mathrm{N}^{\circ} 15$ (Figure 4c). Here, the water table attains its minimum level (10.48 $\mathrm{m})$ in May and its maximum $(11.78 \mathrm{~m})$ in February for an annual mean amplitude of $\Delta_{3}$ $=1.30 \mathrm{~m}$.

prings

All the springs of this catchment are situated in slope-break areas of the catchment. Hence they are said to be springs of the resurgent type. They equally exhibited weak flow rates. The mean flow rates vary from $0.12 \mathrm{~L} / \mathrm{s}$ in January to $0.30 \mathrm{~L} / \mathrm{s}$ in April (Figure 4d). Throughout the study, the weakest flow rates were recorded in $\mathrm{S}_{2}$ while $S_{1}$ presented the strongest in the catchment.

\section{Physicochemical characteristics of aquifer}

During the aquifer contamination follow up period, temperatures of water presented mean monthly values that fluctuate around $27.0{ }^{\circ} \mathrm{C}$. The $\mathrm{pH}$ remained generally acidic no matter the water point. Its mean values oscillated respectively around 4.8 to 5.4 in wells, and 5.3 to 5.5 in springs. Mineralization in this aquifer depends on the nature of the water point, as witnessed by the conductivity values which vary from 29.1 to $939.5 \mu \mathrm{S} / \mathrm{cm}$. In springs however, this parameter falls between 31.8 and $295.5 \mu \mathrm{S} / \mathrm{cm}$ (Table 1).

The curves of variation of nitrates (Figure 5a) in the catchment show a slight retardation as compared to rainy events in the wells. Wells in lowlands showed a high vulnerability to nitrates. During low water periods, lowland wells registered maximum nitrate values in December $(71.10 \mathrm{mg} / \mathrm{l})$ and January $(70.11 \mathrm{mg} / \mathrm{l})$, while those of $\mathrm{mid}$ slopes were recorded in July $(62.11 \mathrm{mg} / \mathrm{l})$. Meanwhile, minimum values were recorded in July $(9.69 \mathrm{mg} / \mathrm{l})$ for ridge wells still during the same period. In springs, the dynamics of nitrates were synchronous to precipitation intensities and to the habitat density of the study area. Hence, the maximum concentration was observed during high rainfall $(28.9 \mathrm{mg} / \mathrm{l})$ in $\mathrm{S}_{3}$ located in a densely populated environment while $S_{5}$ located in a sparsely populated area, showed the weakest values even reaching $0.0 \mathrm{mg} / \mathrm{l}$ per place in the month of October (Figure 4a). The mean monthly values of nitrate elements in the Biyémé upper stream catchment for the considered period are comprised between 3.2 and $53.2 \mathrm{mg} / \mathrm{l}$ in wells, and between 2.4 and $10.2 \mathrm{mg} / \mathrm{l}$ in the springs. These nitrate contents that fluctuate proportionally with rainfall, increase considerably within the year, and mostly exceed WHO threshold values meant for human consumption (WHO, 2008; 2004).

Curves of Figure $5 b$ for ammonium nitrogen dynamics in the area show a small overlap with regards to the rainfall occurrences no matter the topography in the wells. Thus, this excess in ammonia is brought about by reactions of the soil residual nitrogen. In lowland wells, the maximum concentration was observed in November (102.4 mg/l) and this during the low water 
period, meanwhile the minimum value was recorded in ridge wells in December (0.6 $\mathrm{mg} / \mathrm{l}$ ) still during the low water period (Figure 5b). In springs, the evolution curves show a bimodal progression for $\mathrm{S}_{3}: 17.8 \mathrm{mg} / \mathrm{l}$ in September (flood period) and $24.0 \mathrm{mg} / \mathrm{l}$ in February (low water), while $S_{5}$ was the least polluted spring (Figure 5b). The mean ammonium nitrogen concentrations oscillated between 0.8 and $45.6 \mathrm{mg} / \mathrm{l}$ for wells and between 0.5 and $5.2 \mathrm{mg} / \mathrm{l}$ for springs. These values are largely above norms and represent a real danger for human health if used as drinking water.

The results of chemical analyses of wells and springs water samples collected during the twelve campaigns from July 08 to June 09 were represented on a piper's diagram (Figure 6). On the diagram, a strong dispersion of points indicated that several mineralization processes interact inside this aquifer. On the whole, underground waters of the Biyémé upper stream catchment show mainly carbonate features of calcium and magnesium in springs and sodium-chloride and potassium in wells. Two other features are weakly represented: sodium and potassium carbonate features as well as calcium and magnesium chloride /sulphate features.

\section{Bacteriological contamination of aquifer}

The values of bio-indicators contents of this pollution oscillated between 145 to $7145 \mathrm{CFU} / 100 \mathrm{ml}$ and 83 to $1954 \mathrm{CFU} / 100$ $\mathrm{ml}$ respectively for faecal coliforms and streptococci in wells; and between 622 to $5255 \mathrm{CFU} / 100 \mathrm{ml}$, and 144 to $1707 \mathrm{CFU} / 100$ $\mathrm{ml}$ respectively in springs. The dynamics of faecal streptococci (FS) in wells showed a synchronous progression with rainfall occurrences (Figure 7b). The degree of contamination is linked to the topographic position of the well. Wells of high topography are most vulnerable with maximum values getting up to $24 \times 10^{2} \mathrm{CFU} / 100 \mathrm{ml}$ obtained during low water periods (March 09) meanwhile those of middle and low topographies are less [Figures $7(a, b)$ and 8]. Springs show important concentrations in $\mathrm{S}_{3}$ (Figure 7a) is the most vulnerable with maximum values getting up to $3 \times 10^{4} \mathrm{CFU} / 100$ $\mathrm{ml}$ of FC obtained during flood periods.

Contrary to the curve of faecal streptococci (FS) dynamics in the area of which the evolution does not reveal any remarkable form, that of faecal coliforms (FC) (Figure $7 b$ ) reveals a unimodal trend with a maximum peak at $\left(2 \times 10^{4} \mathrm{CFU} / 100 \mathrm{ml}\right)$ during flood periods (April 09) in wells of high altitude; while the evolution of bio-indicators in springs is almost similar to the FS in the area. Akin to $\mathrm{FC}, \mathrm{S}_{3}$ presents a maximum FS concentration of $10^{4} \mathrm{CFU} / 100 \mathrm{ml}$ obtained in September. The studied points present a bacterial pollution of faecal origin. Wells show maximum concentrations while for springs; only $\mathrm{S}_{3}$ was most vulnerable to contamination by FS.

Figure 7 of the dynamics of Escherichia coli $(E c)$ shows the same trend both for FC and FS. The most vulnerable wells to this element are those of high topography with the maximum value of $2 \times 10^{3}$ CFU/100 $\mathrm{ml}$ obtained in the month of September; and a minimum of 0 CFU/100 ml in the month of November. $S_{3}$ remains the most vulnerable of all springs studied. The densities of Escherichia coli in the aquifer vary from 12 to $309 \mathrm{CFU} / 100 \mathrm{ml}$ in wells while they are 30 to $304 \mathrm{CFU} / 100 \mathrm{ml}$ in springs throughout the hydrological monitoring period considered in this research.

Considering the mean values obtained for the ratios of the mean monthly maxima of the FC/FS content (Table 2) established in the different water points of the catchment, the most probable origin of faecal pollution in water supply points were established following the criteria of the American Agency for the Protection of Environment (Jagals et al., 1995). According to these criteria, the most probable origin of this pollution is human if the ratio is greater than 4; animal if the ratio is less than 0.7 ; human in a mixed 
population if the ratio is between 2 and 4; animal in a mixed population if the ratio is between 0.7 and 1 , and mixed if the ratio is between 1 and 2 . In the Biyémé upper stream catchment, values are from 1.3 to 3.4 in wells from lowland, 0.2 to 2.7 in those of mid-slope and 1.4 to 2.9 in ridges. On the other hand, springs showed values from 1.5 to 3.1 with 2.0 as average value in the whole catchment. According to the values obtained above, the origins of pollution in this study area vary with respect to type of water point and can be human mixed in general.

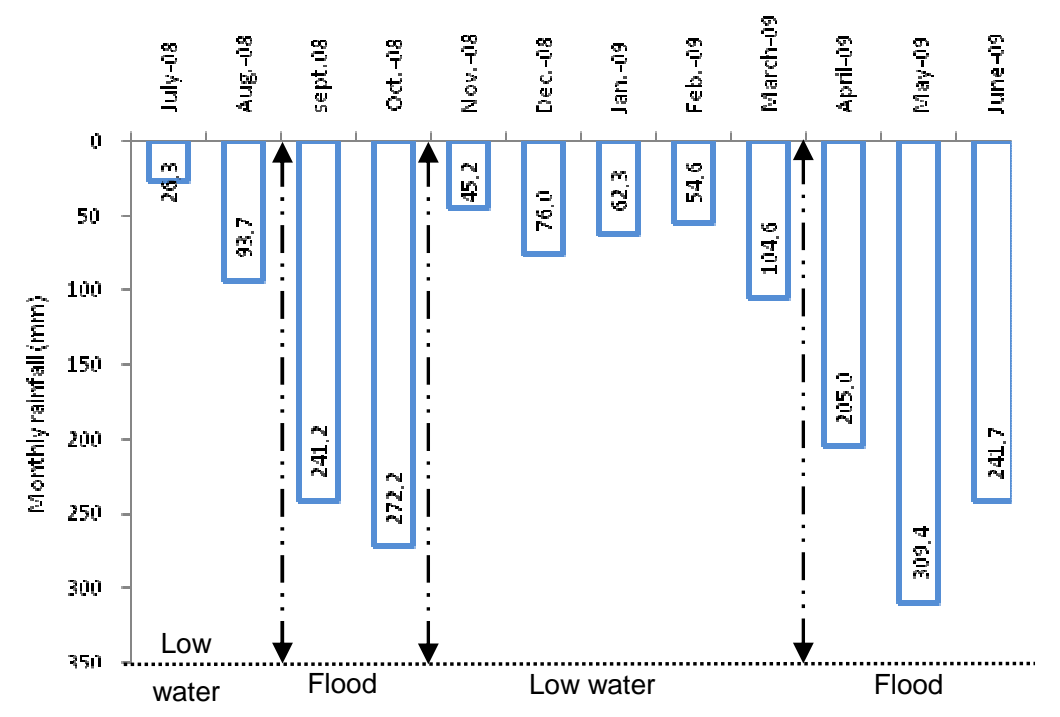

Figure 1: Variations of monthly rainfall in the Yaounde city (period of July 08 to June 09).

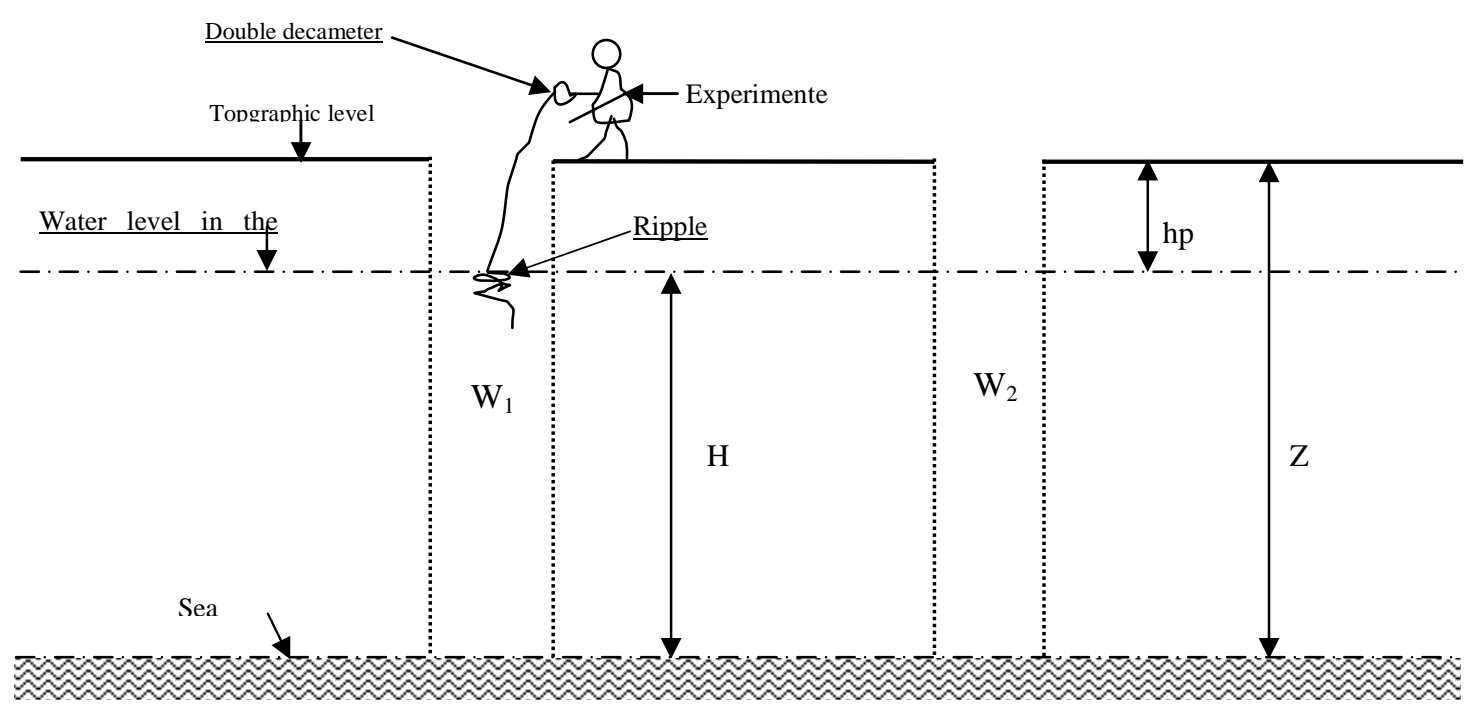

Figure 3: Sketch of manual measurement of the despondencies of the water table in the well. $\mathrm{W}=$ Well; $\mathrm{H}=$ Piezometric level; $\mathrm{Z}$ = Topographic level; $\mathrm{hp}=$ Water depth in the well. 
(a)

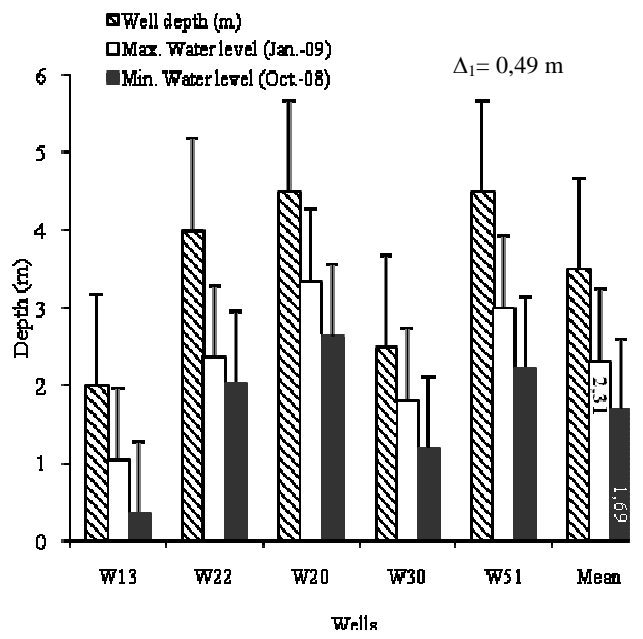

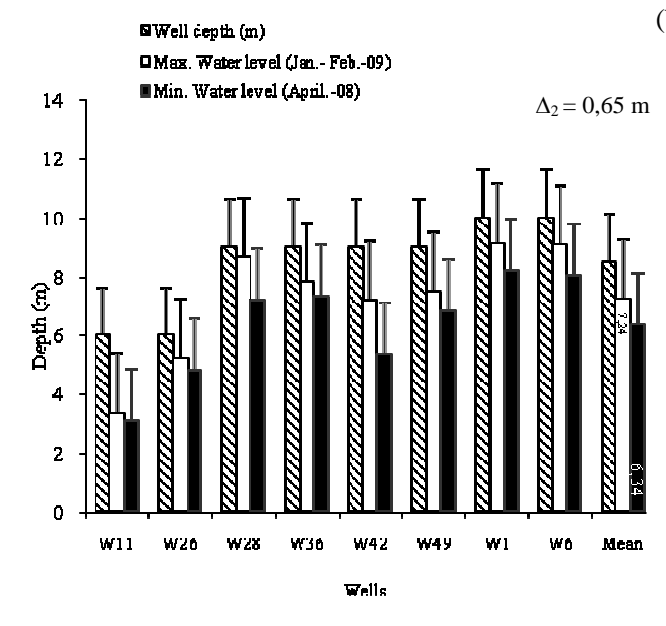

(c)

(b)

(d)
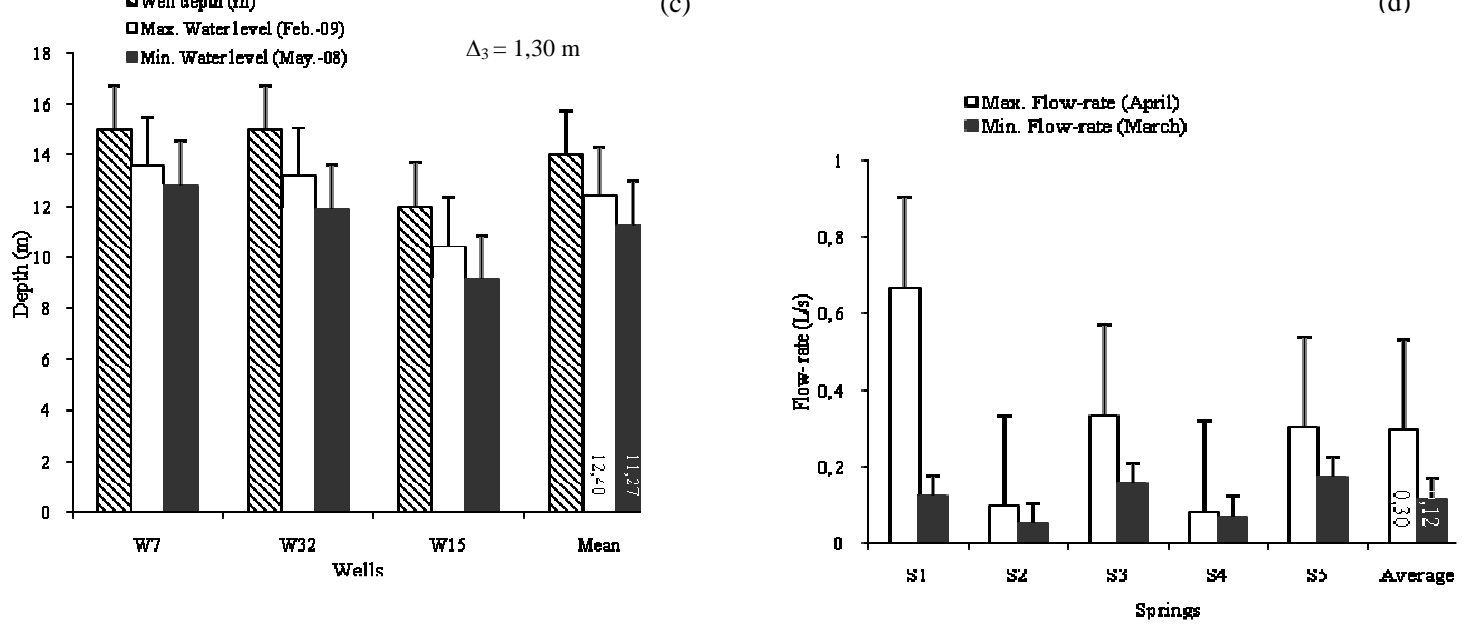

Figure 4: Monthly average of the water lever in wells [Lowland(a) mid-slope(b) and ridge(c)] and the flow- rate of springs (d) in the Biyémé upper stream catchment (July 08 to June 09).

$\mathrm{W}=$ Well; $\mathrm{S}=$ Spring.

\section{DISCUSSION}

Less than $60 \%$ of the population of the city of Yaounde $(2,100,000$ inhabitants $)$ (Bucrep 2005) actually have access to drinkable water; and the city is experiencing a serious drinkable water crisis for about three years now. The only remedy for the compensation of this deficit is wells and springs (Ewodo Mboudou et al., 2009). The results of physicochemical analyses presented in this work showed that the $\mathrm{pH}$, temperature and conductivity of waters of this catchment can be considered as acceptable and do not present any incidence on human health. Hence, the mean values of $\mathrm{pH}$ (5.4), temperature $\left(27.8{ }^{\circ} \mathrm{C}\right)$ and conductivity (291.2 $\mu \mathrm{S} / \mathrm{cm})$ are compatible with the norms required for drinkable water.

These results are in accord with those obtained by Chippaux et al. (2002) on water table of the alluvionary plain of Niamey in Niger, and Saadia et al. (2007), in the gritsandy aquifer of M'nasra in Morocco. 

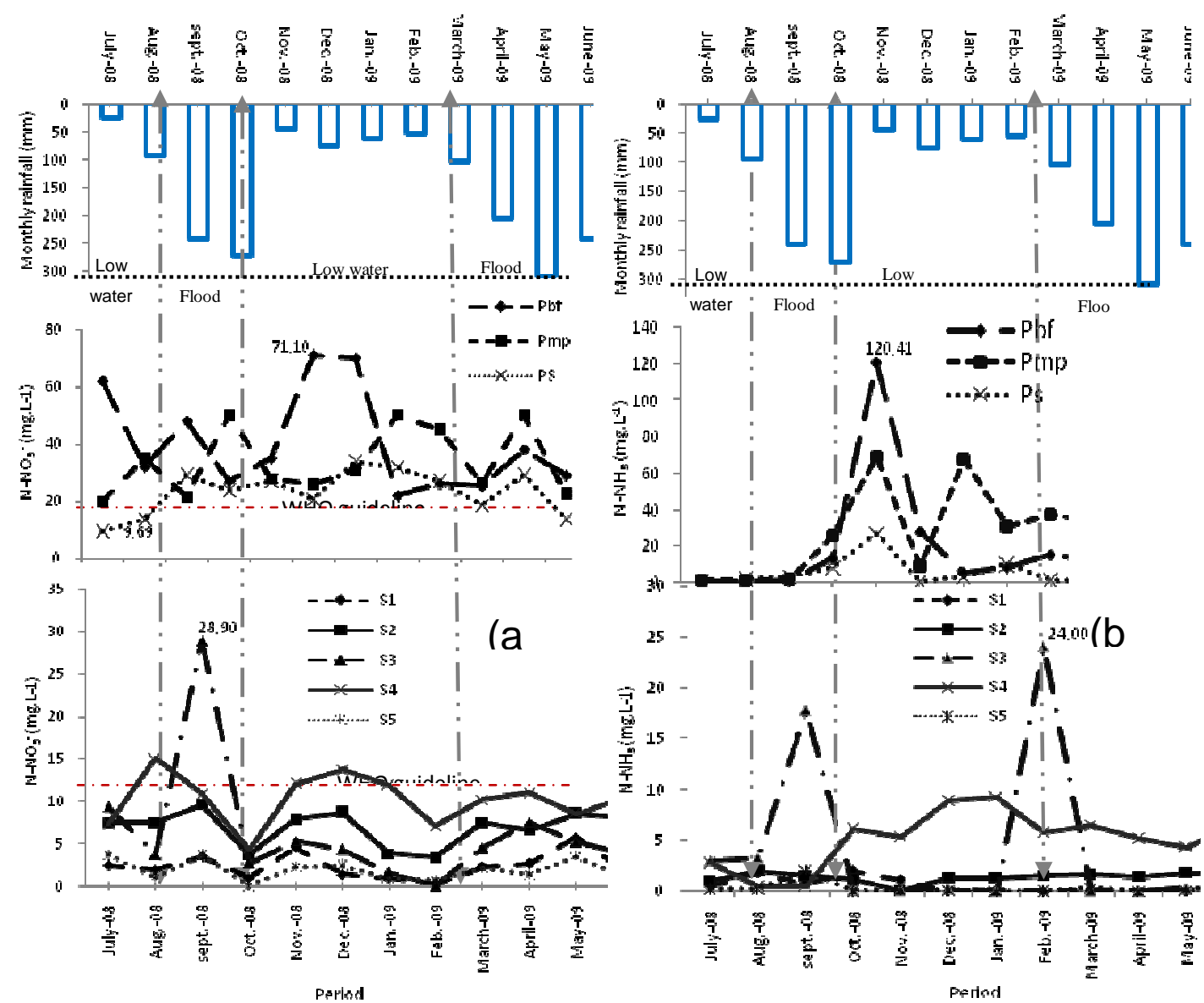

Figure 5: Monthly average variation of Nitrogen components concentration $\left[\mathrm{N}_{-} \mathrm{NO}_{3}{ }^{-}\right.$(a) and $\mathrm{N}-\mathrm{NH}_{3}$ (b)] in wells and springs in relation to the rainfall (July 08 to June 09). Pbf = Wells in lowland; Pmp = Wells of mid slope; Ps = Wells of ridge.

The results obtained confirm the general pollution of the water table of Yaounde to diverse degrees with respect to the location of the water point in the catchment, the depth of the aquifer as well as the rainfall variation in the course of the year. Water points located in the lowlands are generally the most contaminated. This is in accord with the findings of Nola et al. (2000, 2001). Contrary to wells, the results of bacterial pollution of springs of perennial emergence that do not suffer from the instantaneous human action inform more on the intrinsic quality of underground waters for a given region (Boubakar Hassane, 2010). Thus, springs of the Biyémé upper stream catchment gives a better indication on the status of the contamination of this aquifer.

The values of the faecal bio-indicator obtained in the present study corroborates those obtained by Nola et al. (2001) in wells and springs in the whole region of Yaounde and Ewodo Mboudou et al. (2009) of the Mingoso catchment, which is a neighbour to ours $(20>10,000 \mathrm{CFU} / 100 \mathrm{ml}$ for FS and FC). These high values of concentration of faecal pollution of well waters for domestic use in a densely urbanized site are a witness of the direct action of the anthropization of the water table. 


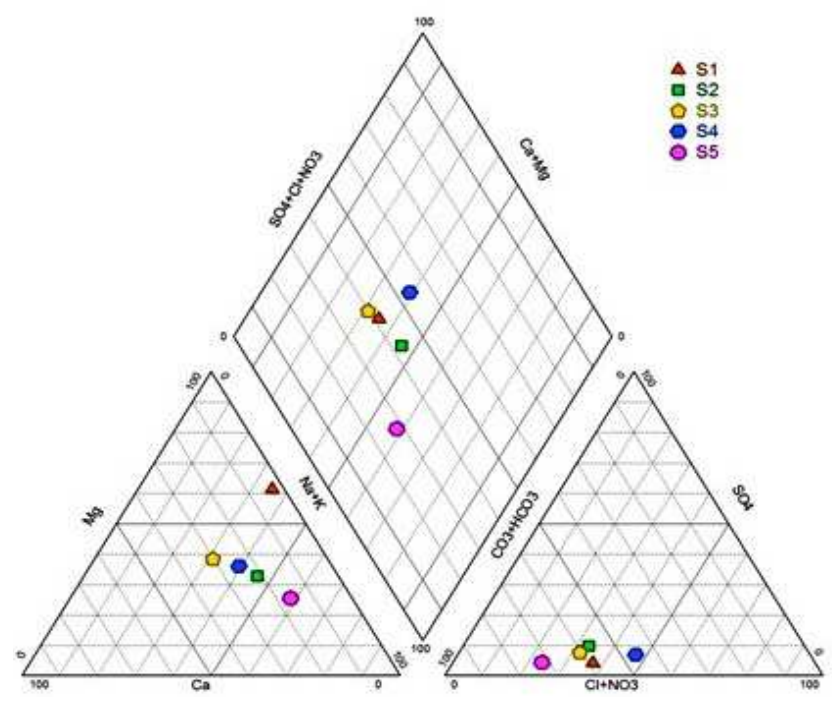

Figure 6: Piper diagram of the Biyémé upper stream catchment groundwater from the period of July 08 to June 09 .

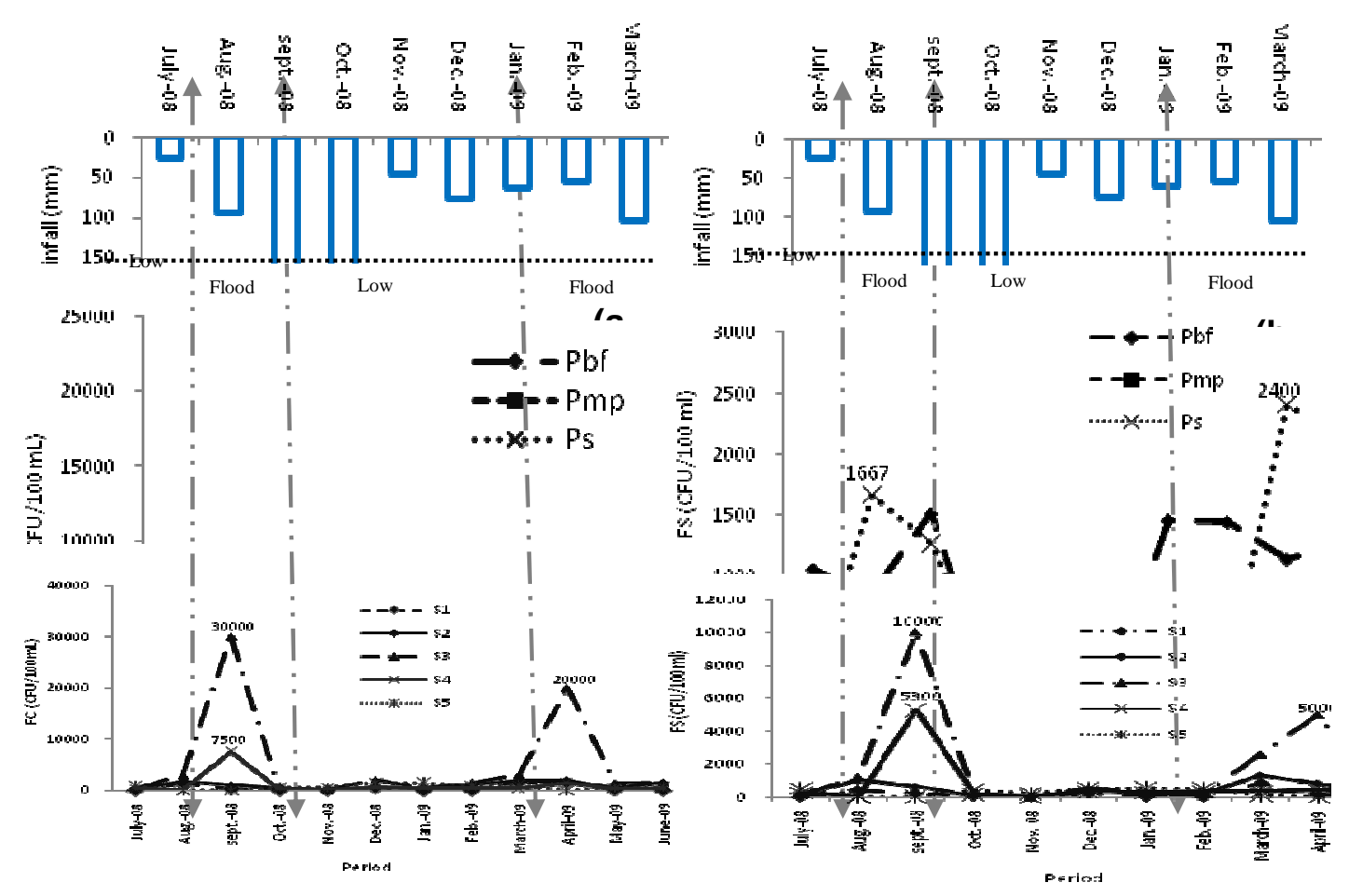

Figure 7: Monthly average variation of the feacal bio-indicators [FC (a) and FS (b)] in wells and springs with respect to rainfall and the topography in the catchment. $\mathrm{Pbf}=$ Wells in lowland; Pmp = Wells of mid slope; Ps = Wells of ridge; $\mathrm{S}=$ Spring. 


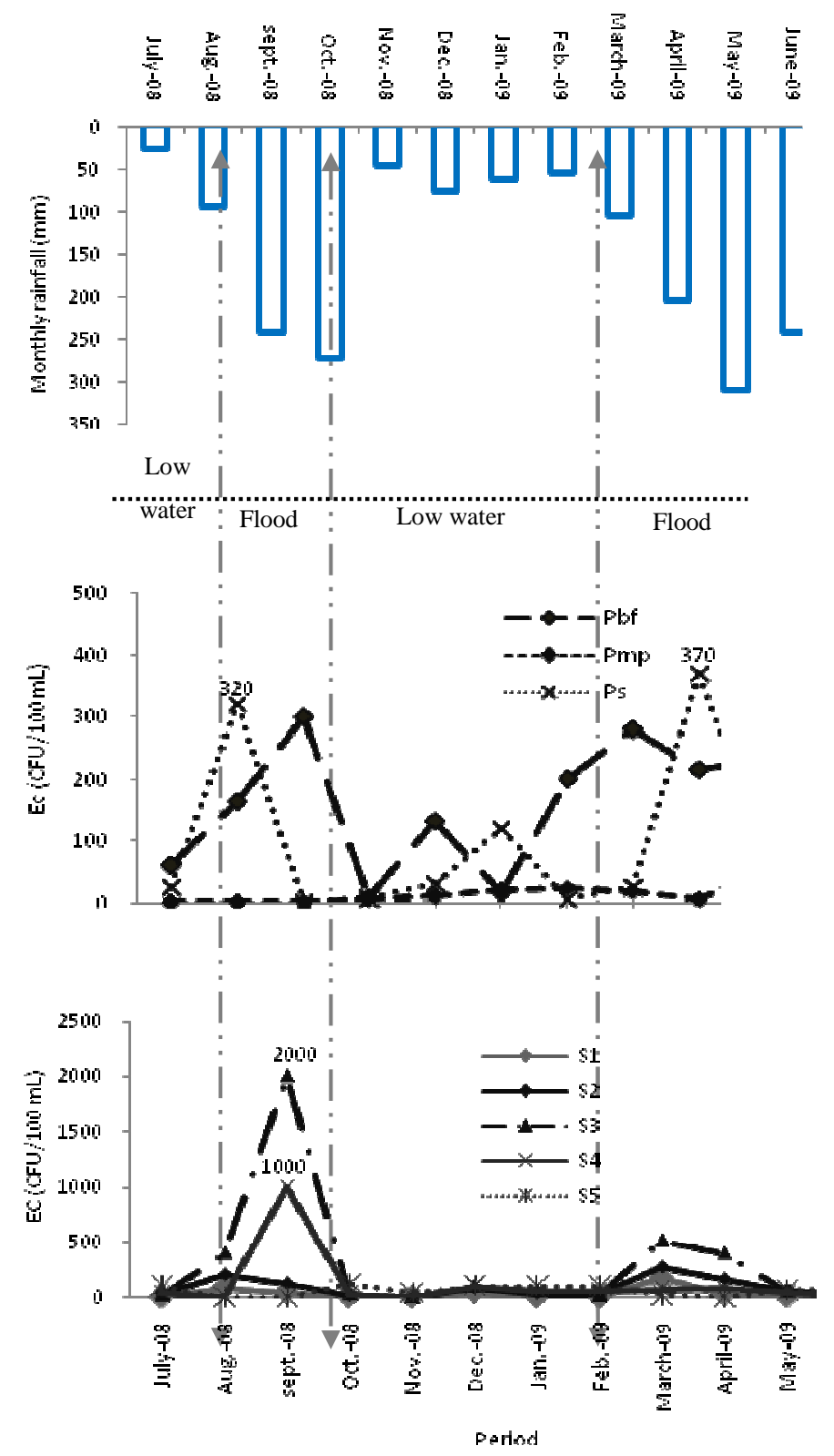

Figure 8: Monthly average variation of Escherichia coli $(\mathrm{Ec})$ content in wells and springs according to the rainfalls and the topography in the catchment.

$\mathrm{Pbf}=$ Wells in lowland; Pmp = Wells of mid slope; $\mathrm{Ps}=$ Wells of ridge; $\mathrm{S}=$ Spring. . 
Table 1: Monthly average concentration of physicochemical pollution in the selected wells and springs for the study in the Biyémé upper stream catchment.

\begin{tabular}{|c|c|c|c|c|c|c|}
\hline \multicolumn{3}{|c|}{ Water points } & \multicolumn{4}{|c|}{ Studied parameters } \\
\hline Type & Location & Code & pH & $\mathbf{T}\left({ }^{\circ} \mathbf{C}\right)$ & E.C. $(\mu \mathrm{S} / \mathrm{cm})$ & Aquifer \\
\hline \multirow{16}{*}{$\frac{n}{3}$} & \multirow{5}{*}{ Lowland } & W13 & 5.0 & 27.9 & 112.1 & Alluvial \\
\hline & & W20 & 5.4 & 27.8 & 650.6 & Alluvial \\
\hline & & $\mathrm{W} 22$ & 5.3 & 27.8 & 522.0 & Alluvial \\
\hline & & W30 & 4.8 & 27.8 & 431.3 & Alluvial \\
\hline & & W51 & 5.0 & 27.4 & 387.8 & Alluvial \\
\hline & \multirow{8}{*}{ Mid-Slope } & $\mathrm{W} 1$ & 5.6 & 27.9 & 939.5 & Alteritic \\
\hline & & W49 & 4.9 & 27.5 & 271.9 & Alteritic \\
\hline & & W6 & 5.0 & 27.8 & 54.4 & Alteritic \\
\hline & & $\mathrm{W} 11$ & 5.1 & 27.8 & 520.2 & Alteritic \\
\hline & & W26 & 4.9 & 27.8 & 182.4 & Alteritic \\
\hline & & W28 & 4.9 & 27.7 & 238.3 & Alteritic \\
\hline & & W36 & 4.9 & 27.8 & 112.7 & Alteritic \\
\hline & & $\mathrm{W} 42$ & 4.7 & 27.7 & 255.4 & Alteritic \\
\hline & \multirow{3}{*}{ Ridge } & W7 & 5.4 & 28.0 & 29.1 & Alteritic \\
\hline & & W32 & 4.8 & 27.9 & 162.6 & Alteritic \\
\hline & & W15 & 4.8 & 27.8 & 201.8 & Alteritic \\
\hline \multirow{5}{*}{$\begin{array}{l}\text { 足 } \\
\stackrel{0}{\Xi} \\
\text { 苟 }\end{array}$} & & $\mathrm{S} 1$ & 5.4 & 27.9 & 54.3 & Re-emergent \\
\hline & & $\mathrm{S} 2$ & 5.5 & 27.8 & 116.7 & Re-emergent \\
\hline & & $\mathrm{S} 3$ & 5.4 & 27.8 & 97.1 & Re-emergent \\
\hline & & S4 & 5.3 & 27.8 & 295.5 & Re-emergent \\
\hline & & S5 & 5.3 & 27.8 & 31.8 & Re-emergent \\
\hline $\begin{array}{c}\text { WHO } \\
\text { Standard }\end{array}$ & & & $6.5-8.5$ & 25.0 & $<100$ & \\
\hline
\end{tabular}


Table 2: Monthly report of average concentration of bio-indicators in wells and springs and the probable origin of faecal pollution in the Biyémé upper stream catchment.

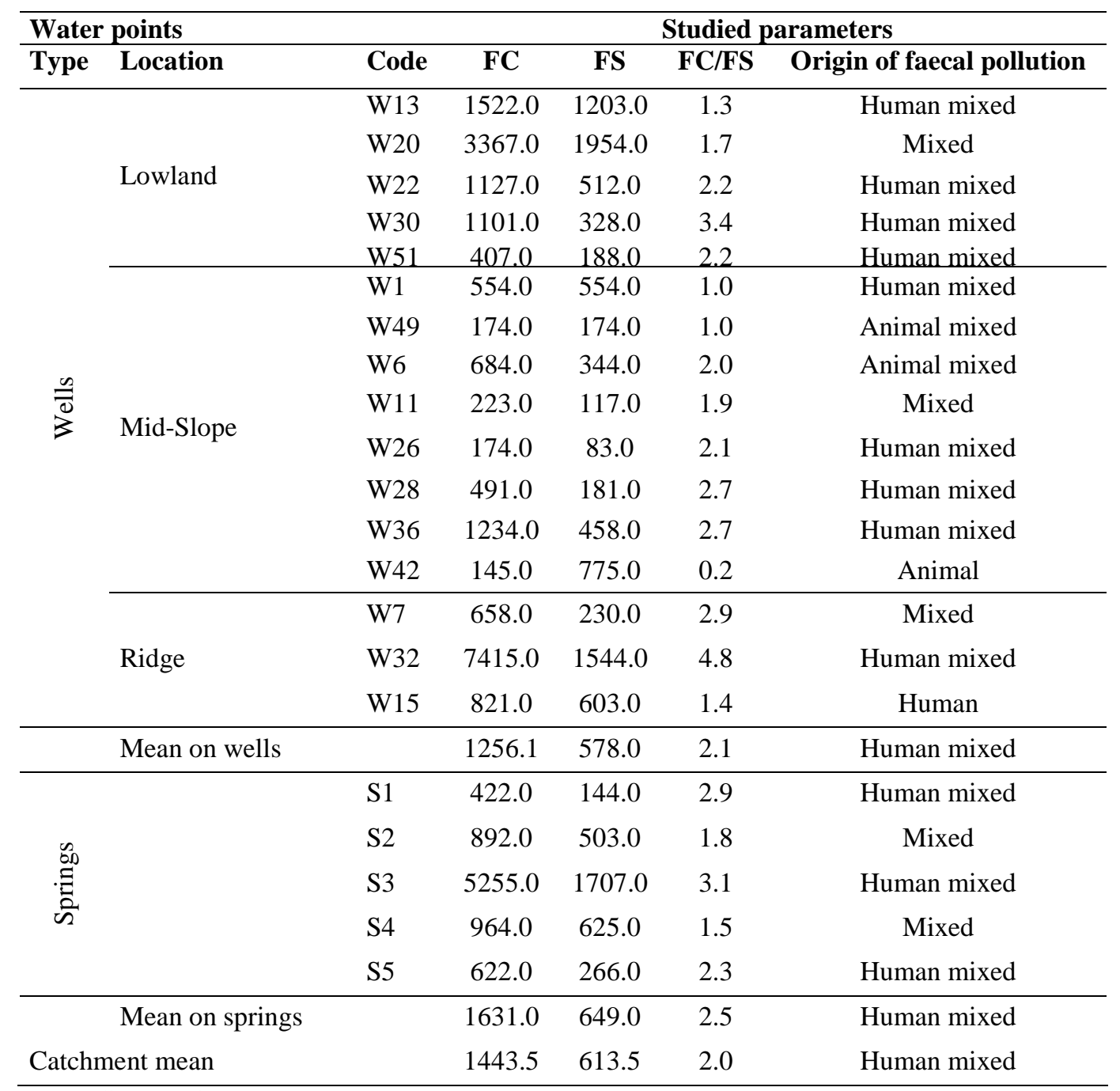

$\mathrm{W}=$ Well; S = Spring;

A longitudinal projection of water points confirms the seasonal variation and stability of the phenomenon throughout the year. Nonetheless, the latter is more rapid in springs than in wells. This difference in reaction of water table throughout the water points is directly linked to the more or less fissured nature of the basic substratum. Springs that are situated in depressions and zones of abrupt rupture of the slope of the catchment showed a quick response to the water table following rainfall occurrences. Hence, the characteristic curves of the dynamics of pollutants in springs showed maximum concentration peaks with maximum intensity of precipitations wells responding only later (Figures 5, 6 and 7). However, analyses of these graphics show that the 
contamination process in wells, especially those located in lowlands are constant in their progression throughout the year. In lowlands zones, bacteria are allochtonous and originate from the propagation of infiltrated microorganisms subsequent to the pollution of underground waters by runoff (surface wastewaters), the transfer of microorganisms in the soil occurring by means of vertical and horizontal infiltrations of the surface waters (Mayer et al., 1997; Dzeda et al., 1998). Hence, the risks of chemical and biological pollution depend partly on the characteristics of infiltration waters and on the natural properties of the geological layers that separate water table from the soil surface. Wastewaters, therefore, constitute the main "vector" for the transfer of microorganisms in the soil. Boutin (1987) mentioned that the aquifer is more vulnerable when the ceiling of the water table is close to the soil surface, when the overcoming fields of the aquifer are permeable and/or when the superficial pollution sources are important. If the sources of pollution of wells located in the lowlands of the catchment can be easily identified, it is however, difficult to understand the mechanisms of transfer of pollutants for those of the catchment ridge. Bouvier et al. (1986) showed that the infiltration speed at the surface of the soil is weak of the order of 5 $\mathrm{mm} \cdot \mathrm{h}^{-1}$ by reason of the generalized of superficial crusts in the first centimeters, which limits the direct vertical recharge of the water table by rainfall. Leduc et al. (1997) consider that the recharge of the water table occurs at precisely localized zones of water accumulation, notably pools fed by consecutive runoffs following rainfall occurrences. Hence, the concentration of pollutants at the surface is advantageous for their treatment as compared to diffuse sources. The underground water of the study site also presents high nitrate concentration. Saadi et al. (1999) mentioned that nitrates in the soil could be due to the texture of the surface and the lithology; strong precipitations and the absence of plant cover contribute to the rapid lixiviation of nitrates towards the water table. Once in the soil and under oxidizing conditions, nitrogen gets nitrified. Ammonium nitrogen stocked in the soil by absorption during the rainy season gets oxidized progressively with the corresponding drop in the water level and the progression of the nonsaturated zone in the dry season. Nitrogen of nitrate being a very mobile form in contrast to ammonium nitrogen quickly gets to the water table. The most documented impact of nitrates on human health is the risk of formation of methemoglobine, a stable oxidized form of haemoglobin which is unable to release oxygen to the tissues. Potential risks of cancerogenicity and teratogenicity can also be associated to the ingestion of nitrates (Laferriere et al., 1995). The presence of pollutants especially bacterial pollutants in the water points located in the ridge of the catchment is more disturbing and could signify a general insalubrity of underground waters of the city of Yaounde. The ratios of mean monthly maxima of FC/FS contents established in the different water points of the catchment scale between 1.4 and 2.5 for a general average of 2.1 (Table 2). These ratios testify that the waters of the wells and springs of water supply from the Biyémé upper stream the catchment presented a faecal pollution of diverse origins which can either be human mixed to human strictly.

\section{Conclusion}

Several results of studies carried out since the days of Bemmo et al. (1998), then those of Nola et al. (2000, 2001), underlined the pollution of the Yaounde aquifer, with its consequent potential sanitary risk. But it was difficult then to evaluate the importance and most especially the spatio-temporal dynamics of the latter, because the methodology used for these studies were on a large scale area with a quite high error margin. Our research 
allows, from this point of view, for the precision of the importance of the pollution and its potential origins in a closed and reduced surface. Hence, wells of low depth and frequently influenced by floods and dryness of the draining water course of the catchment appear to be strongly contaminated by organic matter of human and animal origin. This pollution is directly linked to the insufficiency of sanitation infrastructures and/or domestic waste collector systems. The springs on the other hand did not present a strong contamination throughout the study and the few registered peaks in the months of September and April, are most often nothing but the result of an instantaneous soiling especially when surface wastewaters are not well drained. In qualitative terms, the analyses of piper's diagram reveals that no matter the season, two major types of features and an evolution towards a third feature are characteristic of these underground waters. These are calcium and magnesium bicarbonates for waters from springs, and chlorides of sodium and potassium with an evolution towards a sodium sulphate features for wells. This result shows that geological processes in majority are the ones controlling the mineralization of groundwater in this catchment; and these latter are strongly influenced by water-rock interactions. Nevertheless, anthropic contributions considerably modify the mineralization of these underground waters. The relation between seasonal piezometric fluctuations and seasonal variations of the total mineralization in the different aquifers strengthen this conclusion. Nitrates here are non- negligible by reason of their great spatial variability. In effect, more than $53 \%$ of the sampled water points showed nitrate concentrations higher than the WHO norm of $\left(11.36 \mathrm{mg} / \mathrm{l} \mathrm{N}-\mathrm{NO}_{3}{ }^{-}\right)$ for the safety of drinkable water. Urbanization is the factor favouring an increase in the mineralization of underground waters. This is justified by the fact that the quality of water varies considerably between neighbouring wells and reveals a punctual pollution character. The degree of pollution observed in wells, especially those situated in high topographies of the catchment, confirms that this catchment presents a potential sanitary risk especially as these waters are used by the populations for all purposes. Also, more studies should be conducted to monitor the evolution of pollution in the water table and appropriate measures taken to protect this natural resource. In perspective, it should be appropriate to establish a vulnerability map of the catchment showing more vulnerable areas. This mapping should take into account, among other parameters, the aquifer depth; the effective recharge; the nature of the aquifer; soil type; the topography of the well; the impact of the non-saturated and hydraulic conductivity.

\section{ACKNOWLEDGMENTS}

This research benefited from the support of the International Foundation for Sciences (FIS, Sweden), scholarship $\mathrm{N}^{\circ}$ W4378-1.

\section{REFERENCES}

Abu-Ashur J, Joy M, Lee R, Zehlin S. 1998. Movement of bacteria in unsatured soil columns with macrospores. Transaction of the ASAE, 42: 1043 - 1050.

Bemmo N, Njine T, Nola M, Ngamba D. 1998. Impacts des différents dispositifs d'évacuation des eaux de vidange, des eaux usées, des excrétas humains et des déchets solides sur les ressources en eaux, la santé de l'environnement: cas des quartiers denses à habitats spontanés et des zones périurbaines de Yaoundé Cameroun. Proposition de systèmes appropriés tenant compte des contraintes locales. Rapport de recherche.

Boubakar Hassane A. 2010. Aquifères superficiels et profonds et pollution urbaine en Afrique : Cas de la 
communauté urbaine de Niamey. (Niger). Thèse de Doctorat en Sciences de la Terre. Université Abdou Moumouni de Niamey, 249 p.

Boutin C. 1987. L'eau des nappes phréatiques superficielles, une richesse naturelle vitale mais vulnérable. L'exemple des zones rurales du Maroc. Sci., Eau, 6: 357-365.

Bouvier C, Gathelier R, Gioda A. 1986. Campagne de simulation de pluies en milieu urbain Niamey (Niger). Rapport ORSTOM, Niger.

Bucrep. 2005. Livre rapport de présentation des résultats définitifs du $3^{\mathrm{e}} \mathrm{RGPH}$ : BUCREP (Ed), Yaoundé.

Chippaux JP, Houssier S, Gross P, Bouvier C, Brissaud F. 2002. Etude de la pollution de l'eau souterraine de la ville de Niamey (Niger). Cahier Santé Publique, 2322 : $119-123$.

Davison A, Howard G, Stevens M, Callan P, Fewtrell L, Deere D, Bartram J. 2005. Water Safety Plans, managing drinking water quality from catchment to consumer. Geneva: WHO, Available: http://www.who.int/water_sanitation_ health/dwq/wsp170805.pdf. Accessed May 2009.

Djeuda Tchapnga HB, Tanawa E, Ngnikam E. 2001. L'Eau au Cameroun. Tome 1: Approvisionnement en Eau Potable. Presses Universitaires de Yaoundé; 359 p.

DZEDA B, KAISER M, MACH S. 1998. Bacteria and groundwater. Soil and Groundwater Pollution. Civil Engineering Dept., Virginia Tech. http://www.cee.vt.edu/program-areas/ environmental/ teach/gwprimer/bacteria. html.

Eaton DA, Lenore SCI, Arnold EG. 2005. Standard Methods for the Examination of Water and Wastewater (21 ${ }^{\text {th }}$ edn). APHA, AWWA, WEF Editions: Washington, DC.
Ewodo Mboudou G, Ntep F, Ekwelgen C, Ekodeck GE. 2009. Urbanisation et dégradation spatio-temporelle de la qualité des eaux souterraines dans la zone ouest de la ville de Yaoundé: cas des bassins versants de la Mingosso et de l'Abiérgué. AEHA, 2009.

Frenchel T. 2001. Microorganisms (microbes). Role of Encycl. Biodiversity, 4: 207-219. Proceedings of the 1st MIT conference on CFSM. Cambridge, MA.

Gounot AM. 1994. Microbial ecology of groundwater. In Groundwater Ecology. GIBERT J, STANFORD J (eds). Academic Press: San Diego; 189 - 219.

Growe A, Schaefer Kohut A, Schikaze S, Ptaeck C. 2003. Qualité des eaux souterraines. Série d'ateliers du CCME: Sci., Eau, pol. Winnipeg Manitoba (Ed).

Howard G. 2003. Water safety plans for small systems: a model for applying HACCP concepts for cost-effective monitoring in developing countries. Water Sci Technol., 47: 215 -220.

Hunter PR, MacDonald AM, Carter RC. 2010. Water Supply and Health. PLoS Med, 7(11): e1000361.doi:10.1371/journal. pmed.1000361

Jagals P, Grabow WOK, De Villiers JC. 1995. Evaluation of indicators for assessment of human and animal faecal pollution of surface runoff. Wat. Sci. Tech., 31: 235241.

Kamgang Beyala V, Ekodeck GE. 1991. Altération et bilans géochimiques des biotites des gneiss de Nkolbisson (NW de Yaoundé, Cameroun). Géodynamique, 6(2): 1991.

Laborde JP. 2009. Eléments d'Hydrologie de Surface. Ecole Polytechnique de l'Université de Nice-Sophia Antipolis : Nice, France ; 202 p.

Laferriere M, Nadeau A, Malenfant G, Minville JJ. 1995. La Contamination par les Nitrates des Puits Prives En Milieu Rural: Prevention des Risques à La 
Sante Usp du Centre Hospitalier Regional du Grand-Portage. CLSC Rivières \& Marées Edition.

Leduc C, Bromley J, Schroeter P. 1997. Water table fluctuation and recharge in semiarid climate: some results of the Hapexsahel hydrodynametric survey (Niger). $J$., Hydrol., 9: 123 - 138.

Mahmud SG, Shamsuddin SkAJ, Feroze Ahmed M, Davison A, Deere D, Howard G. 2007. Development and implementation of water safety plans for small water supplies in Bangladesh: benefits and lessons learned. J. Water Health, 5: 585 - 597.

Mayer A, Carriere P, Gallo C, Pennell K, Taylor P, Williams G, Zhong L. 1997. Groundwater quality. Water environment. Res., 69: 778 - 844.

Nola M, Njine T, Djuikom E, Sikati Foko V. 2000. Bacterial indicator dynamics in wells as influenced by well depth and well water column thickness in Yaounde (Cameroon). Afr. J., Sci. Technol., 1: 8291.

Nola M, Njine T, Sikati FV, Djuikom E. 2001. Distribution de Pseudomonas aeruginosa et Aeromonas hydrophila dans les eaux de la nappe phréatique superficielle en zone équatoriale au Cameroun et relations avec quelques paramètres chimiques du milieu. Rev. Sci. Eau, 14: $35-53$.

Nzenti JP. 1987. Pétrogenèse des migmatites de Yaoundé(Cameroun) : éléments pour un modèle géodynamique de la chaîne pan-africaine Nord-Equatoriale. Thèse
Doctorat nouveau régime, Université de Nancy 1, France. p. 140.

Rodier J. 2009. L'analyse de l'Eau; Eau Naturelle, Eau Résiduaire, Eau de Mer. Doc., tech. 9e édn. Dunod (Ed) : Paris.

Saadi Z, Maaslouhi A, Zeraouli M, Gaudet JP. 1999. Analyse et modélisation des variations saisonnières des concentrations en nitrates dans les eaux souterraines de la nappe M'nasra, Maroc. C. R. Acad. Sci., Sér. 2, Sci. Terre Planètes, 329(8): 579 - 586.

Saadia B, Ounine K, Oulkheir S, El Haloui N, Attarassi B. 2007. Etude de la qualité physicochimique et bactériologique de la nappe phréatique M'nasra, (Maroc). Afr. SCI., 3: 391 - 404.

Sanin S. 2004. Effect of surface properties and flow regime or the transport of bacterial in groundwater an experimental approach. Turk. J. Env, Sci., 28: 317 324.

Sighomnou D. 2004. Analyse et redéfinition des régimes climatiques et hydrologiques du Cameroun : perspectives d'évolution des ressources en eau. Thèse de doctorat d'état ès sciences. Université de Yaoundé I, 290 p.

WHO. 2004. Safe health-care waste management: policy paper. WHO: Geneva:

WHO. 2008. Towards a Global Annual Assessment of Drinking-water and Sanitation. WHO: Geneva. 